Anna Pasek

Szkoła Główna Handlowa

\title{
POJĘCIE ZAUFANIA W SPOŁECZEŃSTWIE NOWOCZESNYM I PONOWOCZESNYM
}

\author{
The concept of trust in modern and post-modern society
}

\begin{abstract}
Streszczenie
Celem artykułu jest zaprezentowanie kluczowych cech (elementów) pojęcia zaufania w społeczeństwie nowoczesnym i ponowoczesnym. Na podstawie przeglądu wybranej literatury przedmiotu z lat 1967-2018 dokonano analizy modeli i definicji zaufania oraz podjęto próbę klasyfikacji tego pojęcia. $Z$ badania wynika, że przemiany społeczne i cywilizacyjne mają wpływ na sposób definiowania zaufania.
\end{abstract}

Słowa kluczowe: zaufanie, społeczeństwo nowoczesne, społeczeństwo ponowoczesne

\begin{abstract}
The aim of the article is to present the key features (elements) of the concept of trust in modern and post-modern society. Based on a review of selected literature on the subject from 1967-2018, models and definitions of trust were analyzed and an attempt was made to classify this concept. The study shows that social and civilization changes affect the way trust is defined.
\end{abstract}

Keywords: trust, modern society, post-modern society

\section{Wprowadzenie}

Zaufanie to niezbędny czynnik relacji międzyludzkich zarówno w życiu rodzinnym, jak i zawodowym. Ma ono szczególne znaczenie współcześnie, gdy technologia wyznacza trendy zmian cywilizacyjnych i wpływa na relacje międzyludzkie.

Zaufanie wpływa na zwiększenie efektywności działalności gospodarczej poszczególnych podmiotów w danej gospodarce. Ułatwiona współpraca przyczynia się do szybszego rozwoju, pozwala zaoszczędzić czas, pieniądze, a także wysiłek przeznaczony na pozabiznesową działalność. Jeśli więc ufamy drugiej stronie, czerpiemy wymierne ekonomicznie korzyści (Rudzewicz, Gurziński 2011: 20). Jednak zaufanie to nie towar, którego wymiana na wolnym rynku jest technicznie możliwa czy nawet uzasadniona - podaje Kenneth Arrow, ekonomista i laureat Nagrody Nobla. Zaufanie, podobnie jak wartości pokrewne, tj. lojalność i prawdomówność, to według ekonomistów przykład wartości ubocznych. Według nich nie tylko zaufanie, ale także podobne wartości pokrewne są towarem, mają realną, praktyczną, ekonomiczną wartość, zwiększają wydajność systemu, pozwalają produkować więcej dóbr. Z tego wynika, że nie są to towary, których wymiana na wolnym rynku jest technicznie możliwa albo nawet uzasadniona (Arrow 1974: 23). Ilustracją tego zjawiska może być handel w Internecie, który opiera się na zaufaniu (szerzej: Giddens 2002: 17, 2012: 474-511; Bauman 2004: 220-221).

Celem artykułu jest przyjęto opis zaufania w społeczeństwie nowoczesnym i ponowoczesnym. Przyjęto założenie, że definiowanie zaufania może zmieniać się wraz z przemianami społeczeństwa i rozwojem cywilizacji. Postawioną hipotezę zweryfikowano na podstawie przeglądu literatury przedmiotu. 


\section{Pojęcie zaufania - przegląd modeli i definicji}

Zaufanie to kategoria niełatwa do opisania. Podobnie jak szczęście, trudno je zmierzyć. Przedstawiciele różnych dyscyplin naukowych, poczynając od socjologii, a na naukach o zarządzaniu kończąc, przyjmują odmienną optykę badań.

W definicjach polskich badaczy na pojęcie zaufania składają się takie elementy, jak wiarygodność, wiara, przekonanie, nadzieja, lojalność czy też poleganie na kimś (Grudzewski, Hejduk, Sankowska, Wańtuchowicz 2009: 17). Zaufanie to swoisty zakład na temat przyszłych, niepewnych działań innych ludzi. Niweluje ono niepewność przy założeniu, że inni będą postępować podobnie, a przynajmniej neutralnie (Lewicka-Strzałecka 2003: 197; Frykowski 2005: 11; Sztompka 2007: 99). Inne definicje podkreślają, że nasz los w dużym stopniu zależy od innych ludzi, którzy mogą podejmować działania dla nas korzystne lub szkodliwe. Zaufanie, jakim obdarzymy tych, których nie możemy kontrolować lub z kontrolowania których rezygnujemy, jest oczekiwaniem, że będą oni zachowywać się w określony sposób (Wierzbiński 2009: 25). Zaufanie może również wpływać na zadowolenie z siebie oraz na kontakty międzyludzkie (Andrzejewska 2011: 351). Korzyści z jego obecności w życiu społecznym znacznie przeważają nad stratami wynikającymi z nieudanych prób współpracy, a postawa zaufania jest bardziej korzystna niż stosowanie taktyk unikania danej osoby czy instytucji (Prüfer 2016: 81; zob. także Rudzewicz, Gurziński 2011: 21).

W literaturze anglojęzycznej także można odnaleźć różne kierunki rozważań. Na przykład Julian B. Rotter w 1967 r. podawał, że zaufanie to ogólne oczekiwanie jednostki, iż słowo, obietnica, ustne lub pisemne przyrzeczenie innej jednostki lub grupy jest wiarygodne (Wierzbiński 2009: 26-27). Z kolei Georg Simmel podkreślał wymiar wiedzy i niewiedzy współtworzących zaufanie. Jest to na ogół wiara w prawdomówność danej osoby. To znaczenie najczęściej spotyka się w dziedzinie psychologii osobowości (Šmid 2003: 248-249). Natomiast Robert H. Frank (2007) dodaje, że przepływ informacji między potencjalnymi przeciwnikami odbywa się w zgodzie z zasadą ujawnienia informacji, tzn. jeżeli jedna strona ujawni korzystne informacje na swój temat, to inni będą czuli presję, by ujawnili analogiczną informację o sobie, nawet jeżeli jest ona znacznie mniej korzystna. Z kolei według Francisa Fukuyamy (1997: 256) zaufanie kreuje kapitał społeczny, a od wartości kapitału społecznego zależy wynik ekonomiczny danego państwa (podobnie: Covey, Merrill 2009: 17; więcej zob. Blau 1975: 123; Robbis, Delenzo, 2002: 498; Frykowski 2005: 13; Barbalet 2006: 82; Giddens 2012: 98).

Ze względu na to, że termin „zaufanie” ma w literaturze wiele definicji, a także z powodu jego wieloaspektowości, która sprawia, że trudno przyjąć jedno rozstrzygnięcie, sformułowano następujące założenia: po pierwsze zaufanie jest wartością powszechną (dotyczy relacji międzyludzkich); po drugie jest nieuregulowane prawnie(mowa tutaj m.in. o percepcji tworzenia doświadczenia i wiedzy o otoczeniu, spojrzeniu na zachowanie jako funkcję przyszłych i teraźniejszych zachowań albo cech charakteru człowieka); po trzecie jest odbierane subiektywnie. Warto również podkreślić, że świat się zmienia niezależnie od naszych poczynań - zarówno z przyczyn naturalnych (np. trzęsienia ziemi, powodzie, pożary), jak i na skutek działań podejmowanych przez innych ludzi (np. panika lub krach na giełdzie, protesty społeczne, wkroczenie armii na teren obcego państwa). Jednak my także mamy wpływ na zmiany zachodzące na świecie (Sztompka 2007: 99). Potwierdzeniem mogą być potrzeby społeczne wynikające z rozwoju społeczeństwa, np. potrzeba komunikacji w Internecie czy w organizacji, która prowadzi m.in. do wykorzystania nowych technologii (Podolski, Turnowiecki 2001: 35; Sztompka 2005: 23).

Tabela 1 przedstawia wybrane interpretacje pojęcia zaufania z lat 1967-2018. Zmiany w obrębie słów kluczowych odzwierciedlają przemiany społeczne oraz trendy na świecie. Można zauważyć, że słowa kluczowe związane z zaufaniem dążą do kompetencji i uniwersalności, empatii związanej z predyspozycjami poznawczymi drugiej osoby. Zarówno od/do człowieka, jak i od/do organizacji/instytucji. Odnosi się to m.in. do pierwszego kontaktu z danym człowiekiem lub instytucją. Zagadnienie to jest bardzo rozległe i stanowi materiał do odrębnych badań. 
Tabela 1. Wybrane sposoby interpretacji pojęcia zaufania

\begin{tabular}{|c|c|c|}
\hline Autor (rok) & Definicja zaufania & $\begin{array}{l}\text { Słowa kluczowe } \\
\text { (elementy } \\
\text { zaufania) }\end{array}$ \\
\hline Rotter (1967) & $\begin{array}{l}\text { Oczekiwanie jednostki, że słowo, obietnica, ustne lub pisemne przyrze- } \\
\text { czenie innej jednostki lub grupy jest wiarygodne. }\end{array}$ & $\begin{array}{l}\text { Oczekiwanie, } \\
\text { obietnica, słowo }\end{array}$ \\
\hline Arrow (1974) & $\begin{array}{l}\text { Środek zmniejszający tarcie wewnątrz systemu społecznego. Jest to } \\
\text { niezwykle wydajny instrument; możliwość polegania na słowie partnera } \\
\text { w interesach pozwala oszczędzić wielu problemów. Nie jest to towar, } \\
\text { który można łatwo kupić. }\end{array}$ & $\begin{array}{l}\text { Możliwości, } \\
\text { instrument }\end{array}$ \\
\hline Luhmann (1979) & $\begin{array}{l}\text { Mechanizm, dzięki któremu aktorzy upraszczają wewnętrzne systemy } \\
\text { interakcji, przyjmując określone oczekiwania odnośnie do przyszłych } \\
\text { zachowań innych i wybierając je z dostępnych możliwości. }\end{array}$ & $\begin{array}{l}\text { Mechanizm, } \\
\text { aktorzy }\end{array}$ \\
\hline Gambetta (1988) & $\begin{array}{l}\text { Poziom subiektywnego prawdopodobieństwa, według którego agent } \\
\text { ocenia, czy inny agent (lub grupa agentów) wykona konkretne działanie, } \\
\text { oraz szacuje, jakie będą skutki tego działania. Ocena jest dokonywana, } \\
\text { zanim nastąpi możliwość skontrolowania działania (a także wtedy, gdy } \\
\text { nie ma pewności, czy taka możliwość kiedykolwiek nastąpi). }\end{array}$ & $\begin{array}{l}\text { Ocena, zmiana, } \\
\text { działanie }\end{array}$ \\
\hline McAllistar (1995) & $\begin{array}{l}\text { Poziom, do którego dana osoba jest przekonana, że powinna działać, } \\
\text { kierując się słowami, czynami i decyzjami innych. }\end{array}$ & Przekonanie, słowo \\
\hline Lin (2001) & $\begin{array}{l}\text { Przekonanie czy oczekiwanie, że partner weźmie pod uwagę nasze inte- } \\
\text { resy w ramach wymiany. }\end{array}$ & $\begin{array}{l}\text { Oczekiwanie, } \\
\text { empatia }\end{array}$ \\
\hline Hardin (2006) & $\begin{array}{l}\text { Ufać to wierzyć, że osoba jest wiarygodna w określonym kontekście } \\
\text { i zdolna do tego, czego od niej oczekujemy. }\end{array}$ & Wiarygodność \\
\hline Sprenger (2009) & $\begin{array}{l}\text { Gotowość zrezygnowania z kontrolowania drugiej osoby, ponie- } \\
\text { waż można liczyć na to, że osoba ta jest kompetentna, nieskazitelna } \\
\text { i życzliwa. }\end{array}$ & $\begin{array}{l}\text { Brak kontroli, } \\
\text { kompetencja }\end{array}$ \\
\hline Yamagishi (2012) & $\begin{array}{l}\text { Zaufanie ma związek z wiarą w kompetencje drugiej osoby i zapewnie- } \\
\text { niem, że wspólne planowanie będzie utrzymane w tajemnicy. }\end{array}$ & Profesjonalizm \\
\hline $\begin{array}{l}\text { van Zeeland-van } \\
\text { der Holst, Henseler } \\
(2018)\end{array}$ & $\begin{array}{l}\text { Kluczowa zmienna pośrednicząca między charakterystycznymi zmien- } \\
\text { nymi powierniczymi i wyjściowymi. Jest rozumiane jako zaangażowanie } \\
\text { i lojalność. }\end{array}$ & $\begin{array}{l}\text { Zaangażowanie, } \\
\text { lojalność }\end{array}$ \\
\hline
\end{tabular}

Źródło: opracowanie własne na podstawie: Grudzewski i in. 2009: 16; Wierzbiński 2009:

26-27; Yamagishi 2011: 23 - 25; van Zeeland-van der Holst, Henseler 2018: 75-110.

Można przyjąć, że zaufanie w literaturze jest interpretowane jako (Grudzewski i in. 2009: 17):

- dyspozycja, czyli mentalny subiektywny stosunek do drugiej strony (ocena, przewidywanie, oczekiwanie);

- decyzja, czyli intencja (zamiar) polegania na niej, przez co ufający staje się zależny od drugiej strony;

- zachowanie, które wypływa z aktu powierzenia czegoś drugiej stronie.

\section{Próba klasyfikacji zaufania}

Klasyfikacja zaufania, podobnie jak jego definiowanie, może mieć wieloaspektowe poziomy, dlatego poniższa analiza stanowi jedynie próbę klasyfikacji. W literaturze spotykamy wiele różnych systematyzacji tego szerokiego pojęcia. Przeważnie za kryterium klasyfikacyjne przyjmuje się wskazanie podstaw zaufania (Grudzewski i in. 2009: 38; więcej zob. Scott 1991: 7; Inglehart 1997; Volken 2002; Frykowski 2005: 30-31; Sztompka 2007: 103; Wierzbicki 2009: 25; Rudzewicz, Gurziński 2011: 19). 
W artykule przyjęto klasyfikacje zaufania, które biorą pod uwagę:

- rodzaj zaufania (np. społeczny);

- typ relacji przez pryzmat zaufania (m.in. kontakty z technologią: korzystanie z portali społecznościowych czy zakupy przez Internet);

- ujęcie zaufania jako właściwość relacji wymiany, podstawa współpracy i norma kulturowa.

Na potrzeby niniejszej analizy rozważano kategorię zaufania społecznego. Można je rozpatrywać jako właściwość relacji wymiany, podstawę współpracy lub normę kulturową. Świadczy to o tym, że równowaga i spoistość społeczeństwa istnieje dzięki wzajemności usług. Relacje między ludźmi charakteryzuje pewna geometria społeczna - opierają się one na schemacie dawania i zwracania równoważnej wartości (Simmel 1950: 387). Zaufanie jest zjawiskiem, które występuje na różnych poziomach życia społecznego (Frykowski 2005: 16):

- wymiar makro, w którym zaufanie jest wzorem kulturowym;

- wymiar mezzo, w którym zaufanie jest elementem więzi społecznej;

- wymiar mikro, w którym zaufanie jest elementem osobowości.

W tabeli 2 przedstawiono trzy aspekty zaufania jako: właściwości relacji wymiany, podstawy współpracy i normy kulturowe, biorąc pod uwagę jego charakter, źródło, występowanie, a także krytyczne odniesienie do każdego z ujęć. Przyjęto, że zaufanie może mieć charakter jednostkowy oraz ponadjednostkowy, społeczeństwo jest bowiem siecią relacji, a jednostka to fragment tej sieci (Simmel 2008: 63). Mowa tutaj również o tworzeniu wartości: kapitału społecznego i wiedzy. Przykładem może być przepływ i tworzenie wiedzy w procesie innowacji (szerzej: Giddens 2012: 818; Sztompka 2016: 286). Przepływ wiedzy i zaufanie do tej wiedzy tworzy nowe teorie i rozwiązania techniczne. Co za tym idzie również w tych wymiarach rozpatrywane są aspekty zaufania (źródło oraz występowanie danego zaufania). Krytyka danej teorii ukazuje możliwość ryzyka w zaufaniu (jest to już jednak temat na kolejną pracę badawczą).

Tabela 2. Zestawienie aspektów zaufania

\begin{tabular}{|c|c|c|c|}
\hline \multirow{2}{*}{ Wyszczególnienie } & \multicolumn{3}{|c|}{ Zaufanie } \\
\hline & $\begin{array}{c}\text { jako właściwość relacji } \\
\text { wymiany }\end{array}$ & jako podstawa współpracy & jako norma kulturowa \\
\hline Charakter & Jednostkowy & Ponadjednostkowy & Ponadjednostkowy \\
\hline \multirow[t]{2}{*}{ Źródło } & $\begin{array}{l}\text { Wynika z istoty wymiany } \\
\text { społecznej }\end{array}$ & \multirow[t]{2}{*}{$\begin{array}{l}\text { Odnosi się do grup i więk- } \\
\text { szych zbiorowości, nie zaś do } \\
\text { jednostek }\end{array}$} & Stanowi element kultury \\
\hline & $\begin{array}{l}\text { Jest formą wyrazu wobec } \\
\text { partnera interakcji, a zarazem } \\
\text { warunkiem wymiany }\end{array}$ & & $\begin{array}{l}\text { Kulturowo uwarunko- } \\
\text { wane może mieć charakter } \\
\text { wybiórczy, np. Polacy } \\
\text { ufają Amerykanom, a nie } \\
\text { Rosjanom }\end{array}$ \\
\hline Występowanie & $\begin{array}{l}\text { Sytuacja, kiedy jednost- } \\
\text { kowe decyzje podejmowane } \\
\text { są w sposób dobrowolny } \\
\text { i wypływają z racjonalnych } \\
\text { przesłanek }\end{array}$ & Koncepcja kapitału społecznego & Kultura zaufania \\
\hline
\end{tabular}




\begin{tabular}{|c|c|c|c|}
\hline \multirow{2}{*}{ Wyszczególnienie } & \multicolumn{3}{|c|}{ Zaufanie } \\
\hline & $\begin{array}{c}\text { jako właściwość relacji } \\
\text { wymiany }\end{array}$ & jako podstawa współpracy & jako norma kulturowa \\
\hline \multirow[t]{3}{*}{ Krytyka teorii } & Indywidualistyczny charakter & $\begin{array}{l}\text { Zaufanie ma wymierną wartość } \\
\text { pragmatyczną }\end{array}$ & $\begin{array}{l}\text { Przeciwieństwem jest kul- } \\
\text { tura nieufności }\end{array}$ \\
\hline & $\begin{array}{l}\text { Charakteryzuje się „dylema- } \\
\text { tem indywidualisty” }\end{array}$ & $\begin{array}{l}\text { Możliwość polegania na słowie } \\
\text { partnera w interesach pozwala } \\
\text { oszczędzić wielu problemów, } \\
\text { ale nie jest to towar, którego } \\
\text { wymiana na wolnym rynku jest } \\
\text { technicznie możliwa }\end{array}$ & Kultura cynizmu \\
\hline & $\begin{array}{l}\text { Indywidualistyczne analizo- } \\
\text { wanie procesów społecznych } \\
\text { sprowadza na manowce } \\
\text { przypadkowości (wykluczenie } \\
\text { poza margines teorii uwa- } \\
\text { runkowań strukturalnych, } \\
\text { czyni porządek społeczny } \\
\text { przypadkiem) }\end{array}$ & $\begin{array}{l}\text { Pułapka low trust proverty trap, } \\
\text { np. brak zaufania do instytu- } \\
\text { cji władzy potęguje zjawisko } \\
\text { alienacji politycznej i wyborczą } \\
\text { absencję, a w konsekwencji } \\
\text { konserwuje niewiarygodny } \\
\text { układ polityczny }\end{array}$ & \\
\hline
\end{tabular}

Źródło: opracowanie własne na podstawie Frykowski 2005: 11-13.

Podstawowym problemem powyżej analizy jest fakt, że zaufanie jest wynikiem interakcji. Jego pojawienie się zależy też od cech drugiego człowieka, takich jak chęć współpracy, towarzyskość, zdolność do tworzenia nowych znajomości. Pojęcie zaufania jest wielowymiarowe, tzn. można je rozważać zarówno na poziomie jednostki, jak i społeczeństwa.

\section{Zaufanie w społeczeństwie nowoczesnym}

Powstanie społeczeństwa nowoczesnego wiąże się z uprzemysłowieniem (industrializacją), czyli produkcją przy użyciu maszyn opartych na wykorzystaniu zasobów energii nieożywionej (np. pary czy elektryczności), występującym początkowo w formie pracy nakładczej, a później manufaktury, by w końcu zmienić się w fabrykę. Stanowiło ono kres społeczeństw tradycyjnych, przednowoczesnych. Powstał świat nowoczesny, a wraz z nim społeczeństwo przemysłowe (nazwane rozwiniętym). Pod wpływem rozwoju techniki oraz procesu globalizacji ewoluował rynek pracy. Zmianie uległy przepisy ról i więzi społeczne, nastąpiło przedefiniowanie wartości (Szacka 2003: 305). Co ciekawe, społeczeństwo nowoczesne jest utożsamiane z pierwszymi w historii państwami narodowymi, kształtuje ono bowiem społeczności polityczne, które są oddzielone od siebie wyraźnymi granicami (Walczak-Duraj 2010: 212).

W tabeli 3 zestawiono cztery typy społeczeństw nowoczesnych: społeczeństwa Pierwszego Świata, społeczeństwa Drugiego Świata, społeczeństwo rozwijające się (społeczeństwa Trzeciego Świata), kraje nowo uprzemysłowione, które ukazują różnorodność społeczeństwa nowoczesnego. Przedstawiono okres ich trwania, charakterystykę oraz właściwe dla każdego z nich cechy kluczowe zaufania. 
Tabela 3. Typy społeczeństw nowoczesnych

\begin{tabular}{|c|c|c|c|}
\hline Typ społeczeństwa & $\begin{array}{c}\text { Okres } \\
\text { trwania }\end{array}$ & Charakterystyka & $\begin{array}{l}\text { Kluczowe cechy } \\
\text { (elementy) zaufania }\end{array}$ \\
\hline $\begin{array}{l}\text { Społeczeństwa } \\
\text { Pierwszego Świata }\end{array}$ & $\begin{array}{l}\text { od XVIII w. } \\
\text { do dziśs }\end{array}$ & $\begin{array}{ll}\text { - } & \text { oparte na produkcji przemysłowej i wolnym } \\
\text { - } & \text { rynku } \\
\text { większość ludzi mieszka w miastach, rolnictwem } \\
\text { zajmują się nieliczni } \\
\text { występuje duże zróżnicowania klasowe, ale } \\
\text { mniej zaznaczone niż w społeczeństwach } \\
\text { tradycyjnych } \\
\text { - są to odrębne społeczności polityczne, występu- } \\
\text { jące w formie państw narodowych } \\
\text { należą do nich: państwa Zachodu, Japonia, } \\
\text { Australia i Nowa Zelandia }\end{array}$ & $\begin{array}{l}\text { Kalkulacja, wiedza, } \\
\text { identyfikacja }\end{array}$ \\
\hline $\begin{array}{l}\text { Społeczeństwa } \\
\text { Drugiego Świata }\end{array}$ & $\begin{array}{l}\text { od początku } \\
\text { XX w. (po } \\
\text { rewolucji } \\
\text { bolszewic- } \\
\text { kiej w Rosji } \\
\text { w } 1917 \text { r.) do } \\
\text { początku lat } \\
90 .\end{array}$ & $\begin{array}{l}\text { - } \quad \text { oparte na przemyśle, ale z centralnie planowaną } \\
\text { i zarządzaną gospodarką } \\
\text { - } \quad \text { w rolnictwie pracuje mały odsetek ludności } \\
\text { - } \quad \text { większó́ wskaźníćludności dość zróżnicowane) } \\
\text { - } \quad \text { utrzymują się nierówności klasowe i odrębne } \\
\text { - } \quad \text { społeczności polityczne lub państwa narodowe } \\
\text { do } 1989 \text { r. należały do nich ZSSR i państwa } \\
\text { Europy Wschodniej, które obecnie zmierzają } \\
\text { w kierunku zachodniego modelu gospodarki } \\
\text { wolnorynkowej }\end{array}$ & $\begin{array}{l}\text { Wiarygodność, } \\
\text { odpowiedzialność, } \\
\text { prawdopodobieństwo }\end{array}$ \\
\hline $\begin{array}{l}\text { Społeczeństwo roz- } \\
\text { wijające się (społe- } \\
\text { czeństwa Trzeciego } \\
\text { Świata) }\end{array}$ & $\begin{array}{l}\text { od XVIII w. } \\
\text { (głównie jako } \\
\text { obszary sko- } \\
\text { lonizowane) } \\
\text { do dziś }\end{array}$ & 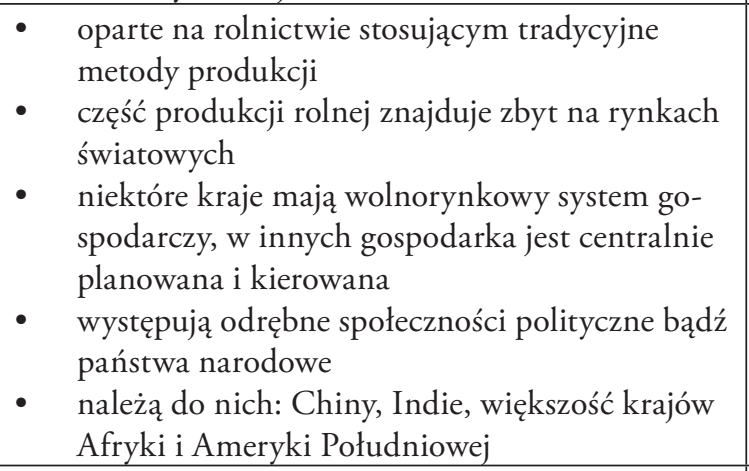 & $\begin{array}{l}\text { Dobra wola, } \\
\text { zachowanie, } \\
\text { poświęcenie } \\
\text { (zaangażowanie), } \\
\text { przewidywalność }\end{array}$ \\
\hline $\begin{array}{l}\text { Kraje nowo } \\
\text { uprzemysłowione }\end{array}$ & $\begin{array}{l}\text { od lat 70. XX } \\
\text { w. do dziś }\end{array}$ & $\begin{array}{l}\text { - } \quad \text { będące dawnymi społeczeństwami rozwijają- } \\
\text { cymi się, obecnie oparte na produkcji przemy- } \\
\text { słowej i wolnym rynku } \\
\text { większość ludzi mieszka w miastach, rolnictwem } \\
\text { zajmują się nieliczni } \\
\text { - występuje duża nierówność społeczna i klasowa, } \\
\text { bardziej zaznaczona niż w krajach Pierwszego } \\
\text { Świata } \\
\text { należą do nich: Hongkong, Korea Południowa, } \\
\text { Singapur, Tajwan, Brazylia i Meksyk }\end{array}$ & $\begin{array}{l}\text { Poświęcenie } \\
\text { (zaangażowanie), } \\
\text { przewidywalność }\end{array}$ \\
\hline
\end{tabular}

Źródło: opracowanie własne na podstawie Walczak-Duraj 2010: 212.

Poszczególne zmienne (typy społeczeństwa) wpływają na określenie elementów zaufania w społeczeństwie nowoczesnym. Zaufanie kształtuje kalkulacje kosztów i korzyści płynących z danej relacji, wiedzę, identyfikację, wiarygodność, prawdopodobieństwo, dobrą wolę, zachowanie, poświęcenie (zaangażowanie), przewidywalność, jest więc stymulatorem działania (zachowania). Czy podobne zjawisko można zaobserwować w społeczeństwie ponowoczesnym? 


\section{Zaufanie w społeczeństwie ponowoczesnym}

Zaufanie w społeczeństwie ponowoczesnym wiąże się z nową formą zaufania, niezbędnego do poczucia bezpieczeństwa i ciągłości życia społecznego. Społeczeństwo to nastawione jest na konsumpcjonizm i życie w świecie wirtualnym. Nowa forma zaufania wynika z założenia, że wszyscy jesteśmy tylko ludźmi, jesteśmy omylni i historycznie uwarunkowani oraz że nikt z nas nie może rościć sobie prawa do wyższego statusu niż status interlokutora w rozmowie (Mariański 1998: 31).

Wśród wielu koncepcji odnoszących się do społeczeństwa ponowoczesnego na uwagę zasługuje przede wszystkim koncepcja określająca społeczeństwo postindustrialne jako takie, w którym dominuje gospodarka usług, a więc większość zatrudnionych pracuje już przy wymianie informacji oraz w usługach (Bell 1996).

Opisy współczesnej kultury popularnej, zarówno krytyczne, jak i przyjazne, odnoszą się w gruncie rzeczy do niewielkiej liczby rozwiniętych społeczeństw przemysłowych, tj. takich, w którym wysoki poziom rozwoju techniki i gospodarki oraz towarzyszący im wzrost dobrobytu spowodował tak daleko idące zmiany, że stały się społeczeństwami nowego rodzaju i zyskały nazwę społeczeństw ponowoczesnych. Najbardziej wyrazistym przykładem takiego społeczeństwa są Stany Zjednoczone (Szacka 2003: 427; więcej zob. Bauman 1996: 45; Morawski 1996: 171-174; Beck 2002: 123-137; Bendyk 2006: 88; Bratkowski 2009: 84; Kałużny 2009: 53; Walczak-Duraj 2010: 215; Szlendak, Olechnicki 2017: 176).

W tabeli 4 przedstawiono charakterystykę społeczeństwa ponowoczesnego, biorąc pod uwagę takie elementy, jak: kapitał społeczeństwa ponowoczesnego (mowa tutaj o przestrzeni wirtualnej), cechę atrybutową, powiązanie między kulturą i ekonomią oraz sferę religii. Wyróżniono kluczowe cechy zaufania, które zapewniają bezpieczeństwo (w kontakcie z technologią) i ciągłość życia społecznego.

Tabela 4. Charakterystyka społeczeństwa ponowoczesnego

\begin{tabular}{|l|l|l|}
\hline \multicolumn{1}{|c|}{ Wyszczególnienie } & \multicolumn{1}{|c|}{ Opis } & $\begin{array}{c}\text { Kluczowe cechy } \\
\text { (elementy) zaufania }\end{array}$ \\
\hline $\begin{array}{l}\text { Kapitał } \\
\text { społeczeństwa } \\
\text { ponowoczesnego }\end{array}$ & $\begin{array}{l}\text { Kapitał jest globalny, zorganizowany i świadomy swych celów. } \\
\text { Przestrzeń fizyczna i przestrzeń wirtualna są traktowane jako jedna, } \\
\text { czy raczej jedyna, przestrzeń społeczna. }\end{array}$ & Uczciwość \\
\hline Cecha atrybutowa & $\begin{array}{l}\text { Charakter konsumpcyjny i dostarczanie przyjemności. } \\
\text { Nowe technologie stosowane w komunikacji. }\end{array}$ & Kontakt \\
\hline Kultura i ekonomia & $\begin{array}{l}\text { Zerwanie z dotychczasowym oddzieleniem kultury od ekonomii. } \\
\text { Specyfika globalności jest mniej lub bardziej wyraźnie zaznaczona. }\end{array}$ & $\begin{array}{l}\text { Zależność, } \\
\text { prawdopodobieństwo }\end{array}$ \\
\hline Religia & $\begin{array}{l}\text { Różne ruchy religijne. } \\
\text { Doświadczenie sacrum zmienia kształt i przybiera nowe formy, np. } \\
\text { religia popularna (treści religijne wychodzą poza instytucje kościelne } \\
\text { i religijne i przenikają do świeckich zwyczajów). Przykładem mogą } \\
\text { być popkulturowe wydarzenia, tzw. eventy religijne (światowe dni } \\
\text { młodzieży). }\end{array}$ & Identyfikacja \\
\hline
\end{tabular}

Źródło: opracowanie własne na podstawie Szacka 2003: 436-444; Walczak-Duraj 2010: 212-220.

Podstawowym problemem ciągłości i bezpieczeństwa życia społecznego w społeczeństwie ponowoczesnym jest zapewnienie kluczowych elementów zachowania, takich jak: uczciwość, kontakt, zależność, prawdopodobieństwo, identyfikacja. Utrzymanie przedstawionych w tabeli 4 cech społeczeństwa ponowoczesnego pozwoliłoby narzucić rytm ciągłości życia społecznego. Wieloznaczność, niepewność, ciągła potrzeba zmian, rozwoju, innowacji i uczenia się są domeną współczesności. Społeczeństwo pod wpływem tych zmian podlega procesowi rozwoju. Jest to wynik oddziaływania instytucji i/lub integrowania ludzi poprzez utrzymanie więzi między nimi. Oczywiście równie ważny wpływ na przemiany społeczne mają potrzeby. Czy faktycznie jednak byłoby to korzystne rozwiązanie? 


\section{Zaufanie w społeczeństwie nowoczesnym i ponowoczesnym - porównanie}

Znakiem rozpoznawczym gwałtownych przemian społecznych jest indywidualizacja i związana z nią pluralizacja stylów życia. W warunkach postępującego rozdziału poszczególnych dziedzin i sfer życia każdy człowiek musi we własnym zakresie aktywnie kształtować swoje życie, podejmować decyzje na rynku wielu możliwości. Tradycyjne wzory życia jednostki przestają obowiązywać, tracą ważność (Mariański 1998: 37).

W tabeli 5 uwzględniono: cechy organizacyjne, cechy osobowości, cechy społeczno-kulturowe, cechy polityczne oraz cechy techniczno-ekonomiczne oraz takie aspekty zaufania, jak właściwość relacji wymiany, podstawa współpracy i norma kulturowa. Zestawienie przedstawia cechy wspólne elementów zaufania w społeczeństwie nowoczesnym i ponowoczesnym.

Tabela 5. Społeczeństwo nowoczesne i ponowoczesne - zestawienie elementów zaufania

\begin{tabular}{|c|c|c|c|}
\hline \multirow[b]{2}{*}{ Wytyczne } & \multicolumn{3}{|c|}{ Kluczowe cechy (elementy) zaufania } \\
\hline & ogólne definicje & $\begin{array}{l}\text { społeczeństwo } \\
\text { nowoczesne }\end{array}$ & $\begin{array}{l}\text { społeczeństwo } \\
\text { ponowoczesne }\end{array}$ \\
\hline $\begin{array}{l}\text { Zaufanie związane jest z istnie- } \\
\text { niem pewnych oczekiwań (m.in. } \\
\text { przyszłości). }\end{array}$ & $\begin{array}{l}\text { Oczekiwanie, obietnica, } \\
\text { słowo }\end{array}$ & $\begin{array}{l}\text { Dobra wola, } \\
\text { zachowanie, } \\
\text { poświęcenie } \\
\text { (zaangażowanie), } \\
\text { przewidywalność }\end{array}$ & $\begin{array}{l}\text { Zależność, } \\
\text { prawdopodobieństwo }\end{array}$ \\
\hline $\begin{array}{l}\text { Zaufanie pojawia się w warunkach } \\
\text { podatności i zależności od zachowań } \\
\text { drugiej strony. }\end{array}$ & Mechanizm, aktorzy & Zachowanie & Kontakt \\
\hline $\begin{array}{l}\text { Zaufanie rozwija się w warunkach } \\
\text { niewymuszonej współpracy. }\end{array}$ & Oczekiwanie, empatia & Zachowanie & Kontakt \\
\hline $\begin{array}{l}\text { Zaufanie istnieje w warunkach nie- } \\
\text { pewności i ryzyka. }\end{array}$ & $\begin{array}{l}\text { Ocena, zmiana, } \\
\text { działanie }\end{array}$ & $\begin{array}{l}\text { Kalkulacja, wiedza, } \\
\text { identyfikacja }\end{array}$ & Identyfikacja \\
\hline $\begin{array}{l}\text { Zachowania nie są kontrolowane } \\
\text { przez stronę ufającą. }\end{array}$ & $\begin{array}{l}\text { Brak kontroli, } \\
\text { kompetencja }\end{array}$ & $\begin{array}{l}\text { Przewidywalność, } \\
\text { zachowanie, }\end{array}$ & Zależność \\
\hline $\begin{array}{l}\text { Strata z powodu zachowania niegod- } \\
\text { nego zaufania jest zazwyczaj znacznie } \\
\text { większa niż przewidywane zyski } \\
\text { z uczciwej działalności. }\end{array}$ & Wiarygodność & $\begin{array}{l}\text { Wiarygodność, } \\
\text { odpowiedzialność, } \\
\text { prawdopodobieństwo }\end{array}$ & Uczciwość \\
\hline $\begin{array}{l}\text { Zaufanie opisuje pewien stopień } \\
\text { przewidywalności. }\end{array}$ & $\begin{array}{l}\text { Przekonanie, słowo, } \\
\text { możliwości, instrument }\end{array}$ & $\begin{array}{l}\text { Poświęcenie } \\
\text { (zaangażowanie), } \\
\text { przewidywalność }\end{array}$ & Zależność \\
\hline $\begin{array}{l}\text { Zaufanie jest z natury pojęciem } \\
\text { pozytywnym. }\end{array}$ & $\begin{array}{l}\text { Zaangażowanie, } \\
\text { lojalność, } \\
\text { profesjonalizm }\end{array}$ & Dobra wola & Uczciwość \\
\hline
\end{tabular}

Źródło: opracowanie własne na podstawie Hejduk, Grudzewski, Sankowska, Wańtuchowicz 2009: 59.

$\mathrm{Z}$ analizy danych zestawionych w tabeli 5 wynika, że społeczeństwo nowoczesne i ponowoczesne cechują te same aspekty zaufania i odnosi się do tego samego wymiaru/obszaru, np. wiarygodności. Znów można potwierdzić, że cechy wspólne pokazują ludzkie działanie, które prowadzą do bezpieczeństwa i ciągłości życia społecznego. Aby zależność ta była trwała, warto zastanowić się nad pojawiającymi się zmianami historycznymi, zaobserwować trendy tych zmian oraz należy uwzględnić możliwe kierunki rozwoju (Pawlak 2018: 119; Szarota 2018: 145). Trzeba jednak pamiętać, że na zmiany trendu społecznego zaufania ma wpływ wiele czynników i mogą ujawnić się one dopiero po pewnym czasie. Ważnym uzupełnieniem podjętych rozważań jest odwołanie do encykliki Jana Pawła II Fiedes et ratio z 1998 r. (19-93), zgodnie z którą wytycznymi rozwoju i trwania są: wiara, etyka i rozum. 


\section{Zakończenie}

W artykule omówiono zagadnienie związane z zaufaniem, społeczeństwem nowoczesnym i ponowoczesnym. Postawiona hipoteza, że definiowanie zaufania może się zmieniać wraz z przemianami społeczeństwa i rozwojem cywilizacji, została potwierdzona.

Świat, w którym żyjemy, w coraz większym stopniu wpływa na celowe działania ludzi. Społeczeństwa są kształtowane i przekształcane. Historia jest nieustannie tworzona i przetwarzana (przez charyzmatycznych przywódców, ruchy społeczne, partie polityczne, rządy, wynalazców, odkrywców, reformatorów itd. (Sztompka 2007: 45). Zaufanie staje się strategią upraszczającą, która pozwala jednostkom zaadaptować się do złożonego środowiska społecznego i tym samym korzystać z większej puli możliwości (Earle, Cvetkovich 1995: 38). Ułatwia radzenie sobie z niepewnością i niemożnością kontrolowania przyszłości (Sztompka 2007: 69-70).

Potrzeba bardziej świadomego zrozumienia zaufania przejawia się w różnych sferach życia. Przykładowo może to być sektor zaawansowanych technologii i usług doradczych. Tam bowiem nie sprzedaje się nic innego jak zaufanie. Jeśli nie ma zaufania, to nie ma przychodów i nie ma mowy o powtórnym przyjściu klienta. Zatem potwierdzają się słowa Piotra Sztompki, że „zaufanie traktowane jest jako istotny czynnik kompetencji cywilizacyjnych" (za: Winnicka 2007: 32).

Opracowanie nie wyczerpuje poruszonego tematu. Może jedynie stanowić punkt odniesienia dla rozważań związanych z tym zagadnieniem i inspirację dla kolejnych prac badawczych.

\section{Bibliografia}

Andrzejewska T.J. (2011), Odpowiedzialność i zaufanie w dialogu interpersonalnym [w:] P. Prüfer, J. Mariański (red.), Zawirowania wokót zaufania. Wyobrażenia i rzeczywistość. Zielona Góra: Oficyna Wydawnicza Uniwersytetu Zielonogórskiego.

Arrow K.J. (1974), The Limits of Organisation. New York: Norton.

Barbalet J.M. (2006), Social emotions: confidence, trust and loyalty. "International Journal of Sociology and Social Policy" 16(9/10).

Bauman J. (1996), Etyka ponowoczesna (tłum. J. Tokarska-Bakir). Warszawa: Wydawnictwo Naukowe PWN. Beck U. (2002), Spoteczeństwo ryzyka. W drodze do nowoczesności. Warszawa: Wydawnictwo Scholar.

Bell D. (1996), The cultural Contractions of Capitalism. New York: Harper \& Row.

Bendyk E. (2006), Natarcie cyfrowych tubylców. „Polityka” 49, s. 88.

Blau P.M. (1975), Wymiana spoteczna [w:] W. Derczyński, A. Jasińska-Kania, J. Szacki (red.), Elementy teorii socjologicznych. Warszawa: Państwowe Wydawnictwo Naukowe.

Bratkowski P. (2009), Duch w krainie konsumpcji. „Newsweek” 21, s. 84.

Covey S.M.R., Merrill R.R. (2009), Szybkość zaufania. Jak dzięki zaufaniu przyspieszyć sukces w biznesie. Poznań: Dom Wydawniczy Rebis.

Earle T., Cvetkovich G. (1995), Social Trust: Toward a Cosmopolitan Society. New York: Praeger.

Frank R.H. (2007), Mikroekonomia jakiej jeszcze nie byto. Gdańsk: Gdańskie Wydawnictwo Ekonomiczne. Frykowski M. (2005), Zaufanie spoteczne mieszkańców Łodzi. Łódź: Wydawnictwo Uniwersytetu Łódzkiego. Fukuyama F. (1997), Zaufanie, kapitat spoteczny a droga do dobrobytu. Warszawa-Wrocław: Wydawnictwo Naukowe PWN.

Giddens A. (2002), Nowoczesność i tożsamość: ja i spoteczeństwo w epoce późnej ponowoczesności. Warszawa: Wydawnictwo Naukowe PWN.

Giddens A. (2012), Socjologia. Warszawa: Wydawnictwo Naukowe PWN.

Grudzewski W.M., Hejduk I.K., Sankowska A., Wańtuchowicz M. (2009), Zarzadzanie zaufaniem w przedsiębiorstwie. Koncepcja, narzędzia, zastosowania. Kraków: Oficyna a Wolters Kluwer business.

Hejduk I.K., Grudzewski W.M., Sankowska A., Wańtuchowicz M. (2009), Znaczenie zaufania i zarzadzania zaufaniem w opinii przedsiębiorstw. „e-mentor” 5(32), s. 59.

Inglehart R. (1997), Modernisation and Postmodernization. Cultural, Economic and Political Change in 43 Societies. Princeton: Princeton University Press.

Jan Paweł II (1999), Fides et ratio [w:] I. Dec, Na skrzydtach wiary i rozumu ku prawdzie. Wrocław. 
Kałużny M. (2009), Z sieciq w tle. „Gazeta Wyborcza” 11, s. 53.

Lewicka-Strzałecka A. (2003), Zaufanie w relacji konsument - biznes. „Prakseologia” 143, s. 195-207.

Scott J. (1991), Social Network Analysis. Sage Publications.

Mariański J. (1998), Między nadzieją i zwątpieniem. Lublin: Towarzystwo Naukowe Katolickiego Uniwersytetu Lubelskiego.

Morawski S. (1996), Czy modernizm rzeczywiście zmierzcha? [w:] S. Czerniak, A. Szahaj (red.), Postmodernizm a filozofia. Wybór tekstów. Warszawa: Instytut Filozofii i Socjologii Polskiej Akademii Nauk.

Pawlak P. (2018), Cyfrowa kultura masowa a kultura polityczna społeczeństwa informacyjnego w perspektywie teorii kultury. Poznań: Wydawnictwo Naukowe UAM.

Podolski K., Turnowiecki W. (2001), Polityka spoteczna. Gdańsk: Wydawnictwo Uniwersytetu Gdańskiego.

Prüfer P. (2016), Relacja i zaufanie jako metamorficzne ogniwo spoteczeństwa [w:] J. Szymczak (red.), Zaufanie spoteczne. Teoria - idee - praktyka. Warszawa: Wydawnictwo Oficyna Naukowa.

Robbins S.P., Decenzo D.A. (2002), Podstawy zarzadzania. Warszawa: Polskie Wydawnictwo Naukowe.

Rudzewicz A., Gurziński J. (2011), Rola w relacjach biznesowych. „Marketing i Rynek” 2, s. 19-22.

Simmel G. (2008), Dygresja w związu z zagadnieniem, jak możliwe jest spoteczeństwo. Warszawa: Oficyna Naukowa.

Szacka B. (2003), Wprowadzenie do socjologii. Warszawa: Oficyna Naukowa.

Szarota P. (2018), Od Facebooka do post-przyjaźni. Wspótczesne przeobrażenie bliskich relacji. Warszawa: Instytut Psychologii, Polska Akademia Nauk.

Szlendak T., Olechnicki K. (2017), Nowe praktyki kulturowe Polaków. Megaceremoniaty i subświaty. Warszawa: Wydawnictwo Naukowe PWN.

Sztompka P. (2005), Socjologia zmian spotecznych. Kraków: Wydawnictwo Znak.

Sztompka P. (2007), Zaufanie fundament spoteczeństwa. Kraków: Wydawnictwo Znak.

Sztompka P. (2016), Kapitat spoteczny. Teoria przestrzeni międzyludzkiej. Kraków: Wydawnictwo Znak Horyzont.

Šmid W. (2003), Psychologia i socjologia zarzadzania - stownik terminów. Sosnowiec: Wydawnictwo Humanitas.

Walczak-Duraj D. (2010), Socjologia dla ekonomistów. Warszawa: Polskie Wydawnictwo Ekonomiczne.

Wierzbińki J. (2009), Badanie zaufania do organizacji: problemy metodologiczne. Warszawa: Wydawnictwo Naukowe Wydziału Zarządzania Uniwersytetu Warszawskiego.

van Zeeland-van der Holst E.M., Henseler J. (2018), Thinking outside the box: a neuroscientific perspective on trust in B2B relationships. "IMP Journal" 12(1), s. 75-110.

Winnicka E. (2007), Towar ttukliwy. Rozmowa z Piotrem Sztompka o tym, że nie można być szcześliwym bez zaufania do drugiego cztowieka i do wtadzy. „Polityka” 32/33, s. 32-35.

Volken T. (2002), Elements of Trust: The Cultural Dimension of Internet Diffusion Revisited. „Electronic Journal of Sociology" 6(4), s. 1-20.

Yamagishi T. (2011), Trust. The evolutionary game of mind and society. New York: Springer. 